\title{
Antibacterial efficacy of leaf extracts of Combretum album Pers. against some pathogenic bacteria
}

\author{
Sunanda Burman ${ }^{1}$, Kuntal Bhattacharya ${ }^{1,2}$, Devaleena Mukherjee ${ }^{1}$ and Goutam Chandra ${ }^{1 *}$ (D)
}

\begin{abstract}
Background: Plant derived medicines show significant contributions to mankind in treating infections of pathogenic bacteria. Recently plants are used in pharmaceutical industries for novel drug preparations because to ensure efficacy and safety as synthetic antibiotics are threatened for their multidrug resistance. The present study aimed at finding antibacterial potential of aqueous and ethanolic leaf extracts of Combretum album.
\end{abstract}

Methods: Antibacterial activity was evaluated against seven bacterial strains by determining minimum inhibitory concentration (MIC) and zone of inhibition. Diameters of the zone of inhibition were compared with standard antibiotics. Preliminary phytochemical screening was done according to standard protocol. FTIR analysis was performed to identify the general phytochemical groups of compounds in the extract. All experiments were conducted in triplicate and values were expressed as the mean \pm standard deviation. One-way analysis of variance (ANOVA) and Tukey tests were performed for statistical justification.

Results: Maximum zones of inhibition were found in case of ethanolic extracts in the following order Bacillus licheniformis (MTCC 530) > Pseudomonas aeruginosa (MTCC 2453) > Bacillus subtilis (MTCC 441) >, Pseudomonas fluorescens (MTCC 103) > Bacillus mycoides (MTCC 7343) > Escherichia coli (MTCC 739) > Pseudomonas putida (MTCC 1654) with zone of inhibition of $27.67 \pm 0.33 \mathrm{~mm}$ diameter in B. licheniformis (MTCC 530). Qualitatively, the ethanol extract contains flavonoids, tannins and alkaloids. The results of FTIR analysis confirmed the presence of R-CH2-OH groups, aromatics, C-N stretching amine and NH stretching secondary amine. One way ANOVA and Tukey tests statistically justify the data $(p \leq 0.05)$.

Conclusions: All the tested leaf extracts showed promising antibacterial activity against both gram positive and gram negative bacteria. Phytochemical screening and FTIR analysis revealed the presence of tannins, alkaloids, $\mathrm{R}-\mathrm{CH} 2-\mathrm{OH}$ groups, aromatics and flavonoids in ethanolic leaf extract qualitatively and these compounds could be responsible for antibacterial property of leaf extracts of C. album.

Keywords: Antibacterial activity, Pathogenic bacteria, Leaf extracts, Combretum album, MIC, Phytochemical screening, FTIR analysis

\footnotetext{
* Correspondence: goutamchandra63@yahoo.co.in

${ }^{1}$ Mosquito, Microbiology and Nanotechnology Research Units, Parasitology

Laboratory, Department of Zoology, The University of Burdwan, Golapbag,

Burdwan, West Bengal 713104, India

Full list of author information is available at the end of the article
}

(c) The Author(s). 2018 Open Access This article is distributed under the terms of the Creative Commons Attribution 4.0 International License (http://creativecommons.org/licenses/by/4.0/), which permits unrestricted use, distribution, and reproduction in any medium, provided you give appropriate credit to the original author(s) and the source, provide a link to the Creative Commons license, and indicate if changes were made. The Creative Commons Public Domain Dedication waiver (http://creativecommons.org/publicdomain/zero/1.0/) applies to the data made available in this article, unless otherwise stated. 


\section{Background}

Pathogenic bacteria are often showing resistance to antibiotics available in markets for treating bacterial infections due to their indiscriminate uses [1]. In addition their use is limited by a number of factors such as low potency, poor solubility and several other side effects [2]. However, plants, being the inexhaustible source of many drugs, have attracted scientists from ancient times as an alternative source of the commercially available antibiotics. Plants are the producers of various effective secondary metabolites which are the active ingredients of herbal medicines [3, 4]. There are plenty of reports in the literature about the antibacterial activity of plant extracts [5-7]. Plant-derived substances have been used from decades owing to their versatile applications in vector borne diseases, fungal infection, diabetes and many more life threatening ailments [8-12].

According to World Health Organization (WHO) [13] herbal medicines derived from medicinal plants would be the best source for curing diseases and provide primary health care to about three quarters of population of developing countries. Herbal drugs and semi-synthetically produced drugs from botanical sources consisting of nearly $78 \%$ of the new drugs approved by the FDA between 1983 and 1994 [14]. Therefore, some herbs, which have been evaluated for antimicrobial activity, may be used to treat a variety of diseases of microbial origin $[15,16]$. Combretum album Pers. (accepted name of C. roxburghii Spreng.) [17] belongs to the ethnobotanically important family Combretaceae. C. album is a small sized climber shrub having simple, opposite, oblong to elliptical leaves [18]. Combretum has several species and they are known for their several pharmaceutical uses like diarrhoea, inflammation, digestive disorder and some Combretum species are also used in diuretic problem [19]. This plant is distributed in India Srilanka, Nepal, Bangladesh, Southern China, Myanmar and along the East Asian countries. Leaves are used in bilious haematuric malarial fever [20] and leaves and bark are known for their antioxidant and cytotoxic activity [21]. Leaves were tested for their antimicrobial properties against some pathogenic bacteria in the present study. Antibacterial effect of C. album was aimed to investigate for suggesting a novel source for a probable herbal drug against several bacterial strains.

\section{Methods}

\section{Plant material}

Fresh mature leaves of Combretum album Pers. (FamilyCombretaceae) were collected from Joypur forest area $\left(23.0540^{\circ} \mathrm{N}, 87.4345^{\circ} \mathrm{E}\right)$, Bankura, West Bengal during February to March 2017. The plant was identified by Professor Dr. Ambarish Mukherjee, Department of Botany, The University of Burdwan. The voucher specimen (Voucher number- GCSB05) was submitted to herbarium of
Mosquito, Microbiology and Nano-technology Research Units, Parasitology laboratory, Department of Zoology, The University of Burdwan.

\section{Preparation of crude extract}

Fresh leaves were collected and rinsed well in distilled water and excess water was soaked on a paper towel. Clean leaves were grinded by an electrical blender and filtered by Whatman's no- 1 filter paper. The filtrate was considered as the stock crude solution (100\% concentration) and stored under refrigeration at $4{ }^{\circ} \mathrm{C}$ for further studies.

\section{Preparation of hot aqueous extract}

For preparation of hot aqueous extract $50 \mathrm{~g}$ of unspotted leaves were minced and boiled in $500 \mathrm{ml}$ of distilled water for $30 \mathrm{~min}$ [22]. The boiled leaves were then kept for $24 \mathrm{~h}$ without any disturbance. Resultant extract was filtered and subjected to lyophilisation. Afterwards the powdered extract thus formed was stored at $4{ }^{\circ} \mathrm{C}$ for future use.

\section{Preparation of cold aqueous extract}

For preparation of cold aqueous extract $50 \mathrm{~g}$ of chopped leaves were soaked into $500 \mathrm{ml}$ of cold water in a stopper bottle in 1:10 ratio [23]. It was left undisturbed for $24 \mathrm{~h}$ and filtered through Whatman's no-1 filter paper. The filtrate thus obtained was lyophilised and then the resultant powder form of extract was kept under refrigeration at $4{ }^{\circ} \mathrm{C}$.

\section{Preparation of ethanol extract}

For preparation of ethanolic extract, fresh and cleaned leaves were shed dried for 14 days. Then $100 \mathrm{~g}$ of the dried leaves were finely chopped and extracted in $1000 \mathrm{ml}$ of ethanol through Soxhlet apparatus following 1:10 ratio [23]. The solvent extraction period was set for $8 \mathrm{~h}$ per day with total $72 \mathrm{~h}$ of extraction period. The extract thus produced was collected from solvent chamber and the excess solvent was evaporated in a rotary evaporator. The residue obtained was stored in a refrigerator for further experiment.

\section{Microorganisms tested}

The tested microorganisms were comprised of three human pathogenic bacterial strains [24] i.e., Bacillus subtilis (MTCC 441), Escherichia coli (MTCC 739) and Pseudomonas aeruginosa (MTCC 2453) and four fish pathogenic bacterial strains [10] namely, B. licheniformis (MTCC 530) B. mycoides (MTCC 7343), P. putida (MTCC 1654), and P. fluorescens (MTCC 103) of clinical importance. The strains were obtained from Mosquito, Microbiology and Nanotechnology Research Units, Parasitology Laboratory, The University of Burdwan. All the 
bacterial strains were cultured in nutrient broth (Hi-Media, M002) at $37{ }^{\circ} \mathrm{C}$ and were maintained on nutrient agar slants at $4{ }^{\circ} \mathrm{C}$.

\section{Determination of antibacterial assay Inoculum standardization}

All bacterial strains were inoculated in Müeller-Hinton broth ( $\mathrm{pH}$ 7.4.) for about $16 \mathrm{~h}$. The concentration of the suspensions was adjusted to 0.5 (optical density) with the help of spectrophotometer.

\section{Assay of antibacterial activity using agar well diffusion method}

Antimicrobial activity of the crude and solvent extracts was determined by the Agar well diffusion method [23]. The $20 \mathrm{ml}$ of sterilized Nutrient Agar was poured into sterile petri plates. After solidification, $100 \mu \mathrm{l}$ of standardized inoculate of each isolate was inoculated on $\mathrm{Nu}$ trient agar plates by using sterilized spreaders. The wells were punched over the agar plates using sterile gel puncher of $6 \mathrm{~mm}$ diameter. $100 \mu \mathrm{l}$ of each extract was poured in to separate wells. Extracts were dissolved in $1 \%(v / v)$ dimethylsulphoxide (DMSO) which was taken as negative control for solvent extract. Four different concentrations of aqueous and ethanolic extracts (50, 100,200 and $400 \mu \mathrm{g} / \mathrm{ml}$ ) were tested. Plates were incubated at $37{ }^{\circ} \mathrm{C}$ for $24 \mathrm{~h}$. Triplets of the experiment were maintained for each bacterial strain to ensure reliability. After incubation the diameter of circular inhibitory zones formed around each well were measured in $\mathrm{mm}$ and recorded.

\section{Antibiotic susceptibility test}

Antibiogram was done by disc diffusion method using standard antimicrobial sensitivity testing antibiotics obtained from Hi-Media Laboratories Limited, Bombay were use. Agar plates were prepared and the test organisms were swabbed over the surface of the solidified agar plates using sterile swab spreader. Then standard antibiotic discs were impregnated on the inoculated agar plates and incubated for $24 \mathrm{~h}$ at $37^{\circ} \mathrm{C}$. This was followed by measurement of zone of inhibition formed by the test bacteria around the standard antibiotic discs [4].

\section{Minimum inhibitory concentration (MIC)}

Standard methods of antimicrobial susceptibility test approved by the National Committee for Clinical Laboratory Science (NCCLS) [25] for testing conventional drugs cannot be exactly applicable to plant extracts. Hence, modifications have been made for evaluating antibacterial activity of active principles of plant origin. Minimum inhibitory concentration (MIC) was determined for each extract showing antimicrobial activity against the test isolates using broth dilution method with slight modifications [25, 26]. Each culture was diluted in Müeller-Hinton broth. The concentration of test cultures was adjusted to turbidity of 0.5 McFarland standards. Equal volume $(0.5 \mathrm{ml})$ of each extract (by serial dilutions from the stock solution of cold aqueous, hot aqueous and ethanol extract) and nutrient broth were mixed in the test tubes. Final concentrations of the three extracts in each of the test tube were in the range of 40 , $35,30,25,20,10,5,2.5,1.25$ and $0.625 \mu \mathrm{g} / \mathrm{ml}$. Specifically $0.1 \mathrm{ml}$ of standardized inoculum $\left(5 \times 10^{5} \mathrm{CFU} / \mathrm{ml}\right)$ was added to each tube. All the tubes were incubated for $24 \mathrm{~h}$ at $37^{\circ} \mathrm{C}$. After incubation growth were examined and data were recorded. The MIC values were taken as the lowest concentration of the extracts showing no growth in the tube. Experiment was repeated thrice for authentication of the data.

\section{Phytochemical screening}

Phytochemical analysis was done using the protocols by Harbone and Sofowora [27, 28] for testing the presence of tannins, saponins, steroids, terpenoids, glycosides, alkaloids, anthroquinones and flavonoids in ethanolic extract of C. album leaves.

\section{Fourier transform infrared spectrophotometer (FTIR) analysis}

Fourier Transform Infrared Spectrophotometer (FTIR) is the most reliable tool for identifying the types of chemical bonds (functional groups) in the plant extracts. Dried powder of ethanol extract of C. album leaves was used for FTIR analysis. For preparing translucent sample discs $10 \mathrm{mg}$ of the dried extract powder was encapsulated in $100 \mathrm{mg}$ of $\mathrm{KBr}$ pellet by using hydrolic press. $\mathrm{KBr}$ pellet was used as control. The pellets were loaded in FTIR spectrometer (Jasco, FT/IR- 4700), with a scan range from 400 to $4500 \mathrm{~cm}^{-}{ }^{1}$ in order to determine the functional groups in the ethanolic extract.

\section{Statistical analysis}

The data were analysed by using MS Excel 2007 and presented as mean $\pm \mathrm{SD}$ of three replicates. One-way analysis of variance (ANOVA) and Tukey tests were performed by using 'Stat plus 2009 professional' trial version software to determine significant group differences and means were considered as statistically significant if $p<0.05$.

\section{Results}

Leaf extracts of C. album showed significant antibacterial activity against the seven tested pathogenic bacteria. In this experiment crude, hot aqueous, cold aqueous and ethanolic extract showed inhibitory property towards all bacterial isolates with $B$. licheniformis (MTCC 530) being most susceptible to the ethanolic extract $(400 \mu \mathrm{g} / \mathrm{ml})$ 


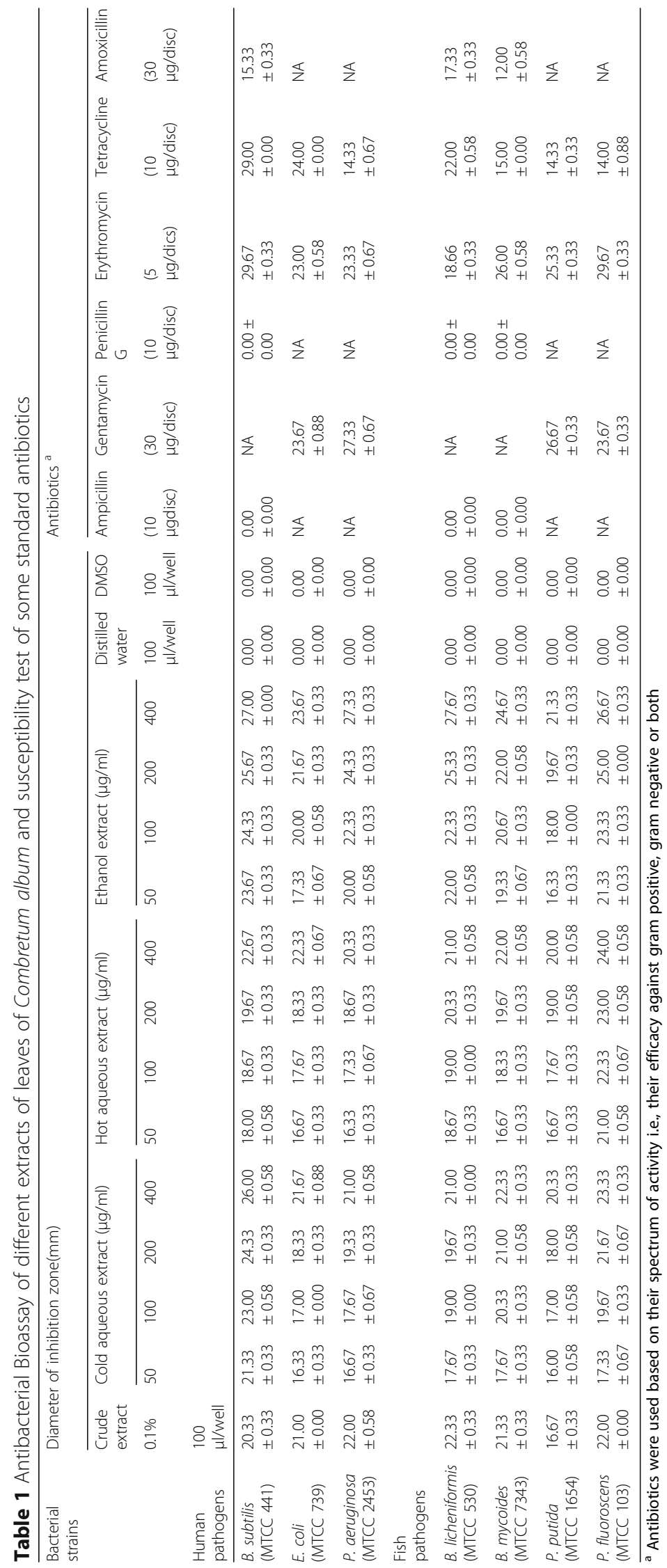


with inhibition zone of $27.67 \pm 0.33 \mathrm{~mm}$ followed by $P$. aeruginosa (MTCC 2453), B. subtilis (MTCC 441), P. fluorescens (MTCC 103), B. mycoides (MTCC 7343), E. coli (MTCC 739), and P. putida (MTCC 1654) with inhibition zones of $27.33 \pm 0.33 \mathrm{~mm}, 27.00 \pm 0.00 \mathrm{~mm}$, $26.67 \pm 0.33 \mathrm{~mm}, 24.67 \pm 0.33 \mathrm{~mm}, 23.67 \pm 0.33 \mathrm{~mm}$ and $21.33 \pm 0.33 \mathrm{~mm}$ of diameter respectively. Whereas negative controls i.e., distilled water and DMSO did not show any inhibitory effect to the growth of all tested bacteria (Table 1). Results of antibiogram in this investigation depicted that all the bacterial isolates were resistant to standard antibiotics like Ampicillin $(10 \mu \mathrm{g} / \mathrm{disc})$ and Penicillin G $(10 \mu \mathrm{g} / \mathrm{disc})$ and also Amoxicillin $(30 \mu \mathrm{g} / \mathrm{disc})$ had very little effect against them. Susceptibility of all the gram negative bacteria to Gentamycin (30 $\mu \mathrm{g} / \mathrm{disc})$, and both gram negative and gram positive bacteria to Tetracycline (10 $\mu \mathrm{g} /$ disc) and Erythromycin $(5 \mu \mathrm{g} /$ disc) was higher among the respective tested antibiotics and the bacterial strains showed differential susceptibility to different antibiotics (Table 1). E. coli (MTCC 739) was most susceptible to Gentamycin $(30 \mu \mathrm{g} / \mathrm{disc})$ while growth of B. subtilis (MTCC 441) was inhibited with maximum inhibition zone by Erythromycin $(5 \mu \mathrm{g} /$ disc $)$ and Tetracycline $(10 \mu \mathrm{g} /$ disc $)$ (Table 1). It was also observed from the result that antibacterial activity of the extracts increased with the increase in the concentration used. MIC was tested with serial dilution of the leaf extracts and the results indicated a very low concentrations were effective (Table 2) against the tested bacterial strains. Analysis of variance table (One way ANOVA) and Tukey test for differences between means demonstrated statistical significance of the data $(p \leq 0.05)$. Phytochemical analysis revealed the presence of secondary metabolites like flavonoids, tannins and alkaloids (Table 3) in the ethanolic extract of C. album. FTIR analysis (Fig. 1) of the ethanolic leaf extract revealed major bands at $2923.56 \mathrm{~cm}^{-1}, 1608.34 \mathrm{~cm}^{-1}, 1282.43 \mathrm{~cm}^{-1}$, $1175.4 \mathrm{~cm}^{-1}$ and $1014.37 \mathrm{~cm}^{-1}$. The bands at 3400 $3200 \mathrm{~cm}^{-1}$ implied to the $\mathrm{OH}$ stretching hydrogen bonded broad peak and $\mathrm{C}-\mathrm{O}$ stretch at bands at 1075$1000 \mathrm{~cm}^{-1}$ confirming the presence of $\mathrm{R}-\mathrm{CH} 2-\mathrm{OH}$ groups (Alcohols). The bands at $1040-995 \mathrm{~cm}^{-1}$ were due to $\mathrm{CH}$ bending in plane $\mathrm{H}$ bend $730-680 \mathrm{~cm}^{-1}$ out of plane ring bending associated with the presence of aromatics in the extract. C-N stretching amine and $\mathrm{NH}$ stretching secondary amine were indicated by bands at $1146-1132 \mathrm{~cm}^{-1}$ and $3500-3300 \mathrm{~cm}^{-1}$. Bands at $1700-1680 \mathrm{~cm}^{-1}, 1320-$ $1211 \mathrm{~cm}^{-1}$ and $960-875 \mathrm{~cm}^{-1}$ unveiled the presence of $\mathrm{C}=\mathrm{O}$ stretching, $\mathrm{C}-\mathrm{O}$ stretching and $\mathrm{O}-\mathrm{H}$ deformation with broad out-of-plane $\mathrm{OH}$...O deformation corresponding to $\mathrm{Ph}-\mathrm{COOH}$ (carboxylic acids) respectively.

\section{Discussion}

Presence of effective phytochemicals in higher plants has been known for their antibacterial activity. Effectiveness of the phytoconstituents may be related to the solvents used for their extraction. In Ayurveda extraction with water and ethanol is well known because of their nontoxic property and edibility. Mukhtar et al. [29] reported the use of aqueous and ethanolic medicinal plant extract for their antimicrobial activity. Similar effects of ethanolic extract observed in the works of many researchers [30-32].

Modes of action of plant extracts that are distinct from those of the antibiotics in current use, suggesting that cross-resistance with agents already in use is negligible [33]. All of the extracts showed a linear antibacterial efficacy to all tested bacteria and therefore supported the statement that there is no correlation between the susceptibility shown by $C$. album extracts and the resistance to any other standard antibiotics tested. MIC (Table 2) is very low in comparison to results of many medicinal plants observed in several other research works [10, 34]. From the results of MIC and zone of inhibition values and their competition to that of the standard antibiotics it can be concluded that the leaf extracts are considered to have a broad spectrum antibacterial activity against both gram positive and gram negative bacteria. It was also evident from the result that antibacterial activity increased with the increase in concentration of all extracts in all tested bacteria (Table 1).

Kumar has reported antibacterial activity of ethanol extract of flower of Combretum indicum, which showed highest inhibition zone $(18 \mathrm{~mm})$ against

Table 2 Minimum Inhibitory Concentration of different leaf extracts of C. album

\begin{tabular}{llll}
\hline Bacterial strains & \multicolumn{2}{l}{ Minimum inhibitory concentration $(\mu \mathrm{g} / \mathrm{ml})$} & \\
\cline { 2 - 4 } & Cold water extract & Hot water extract & Ethanol extract \\
\hline B. subtilis (MTCC 441) & $25.00 \pm 0.00$ & $25.00 \pm 0.00$ & $15.00 \pm 0.00$ \\
P. aeruginosa (MTCC 2453) & $20.00 \pm 0.00$ & $15.00 \pm 0.00$ & $5.00 \pm 0.00$ \\
E coli (MTCC 739) & $30.00 \pm 0.00$ & $20.00 \pm 0.00$ & $15.00 \pm 0.00$ \\
B. licheniformis (MTCC 530) & $20.00 \pm 0.00$ & $15.00 \pm 0.00$ & $5.00 \pm 0.00$ \\
B. mycoides (MTCC 7343) & $35.00 \pm 0.00$ & $25.00 \pm 0.00$ & $20.00 \pm 0.00$ \\
P. putida (MTCC 1654) & $30.00 \pm 0.00$ & $20.00 \pm 0.00$ & $10.00 \pm 0.00$ \\
P. fluoroscens (MTCC 103) & $25.00 \pm 0.00$ & $25.00 \pm 0.00$ & $15.00 \pm 0.00$ \\
\hline
\end{tabular}


Table 3 Secondary metabolites obtained in Combretum album leaves

\begin{tabular}{ll}
\hline Phytochemicals & Ethanol extract \\
\hline Tannins & $+V e$ \\
Saponins & $-V e$ \\
Steroids & $-V e$ \\
Terpenoids & $-V e$ \\
Glycosides & $-V e$ \\
Alkaloids & $+V e$ \\
anthraquinones & $-V e$ \\
Flavonoids & $+V e$ \\
\hline
\end{tabular}

Staphylococcus aureus whereas $P$. aeruginosa showed intermediate sensitivity $(16 \mathrm{~mm})$ at $100 \mathrm{mg} / \mathrm{ml}$ concentration [35]. Oghenejobo et al. [36], while tested ethanolic extract of leaves of Combretum racemosum against S. aureus, P. aeruginosa, Proteus vulgaris, E. coli and Salmonella typhi, highest inhibition zone (25 mm) was observed against $S$. aureus at $31.25 \mathrm{mg} /$ $\mathrm{ml}$ concentration. Present study indicates that $C$. album exhibited much higher antibacterial activity in lesser concentration comparative to $C$. indicum and C. racemosum. Panda et al. [37] reported positive antibacterial effectiveness of aqueous and methanolic bark and leaf extract of C. album against some bacteria such as Staphylococcus aureus, Shigella dysentriae, S. flexneri and Vibrio cholera. Moreover our work was conducted against different bacteria and more significant results were found using aqueous and ethanolic extracts. The compounds responsible for this antibacterial activity though not investigated, preliminary phytochemical analysis of the ethanolic extract exposed the presence of tannin, alkaloid and flavonoid compounds and the presence of alcoholic, amine, carboxylic acids and aromatic groups was revealed by FTIR analysis which supports these findings. According to Hideyuki et al. [38] and Meng et al. [39] flavonoids and tannins may contribute to antibacterial properties. Thus it can be inferred that antibacterial properties of C. album leaf may be attributed to the individual or combined effect of the above mentioned chemical groups [40, 41]. The antibacterial potency of the plants is thought to be due to functional groups like alcoholic, aromatic, amine and carbo-acids present in tannins, alkaloids and flavonoids detected by FTIR analysis which can be extracted from this plant and used in herbal drug preparations valuable for the treatment of many bacteria borne diseases and this should be fully explored in proper approach. This finding could also emphatically contribute to increase the therapeutic value of the particular chemicals in the plant which can be acted as antibacterial agents. The findings of the present study offer the ethnomedical use of this plant by the pharmaceutical industries. Further studies are needed to pin point the active ingredient responsible for antibacterial activity.

\section{Conclusions}

Increase in resistance to commercially available antibiotics projects major dilemma in the treatment of bacterial infections throughout the world. Based on the above investigation it can be concluded that leaves of C. album can be a potential source for herbal drug preparations against pathogenic bacteria. In Future phytochemical group wise screening and isolation of bio-active compounds will be further investigated to develop as a new therapeutic agent to fight infectious diseases.

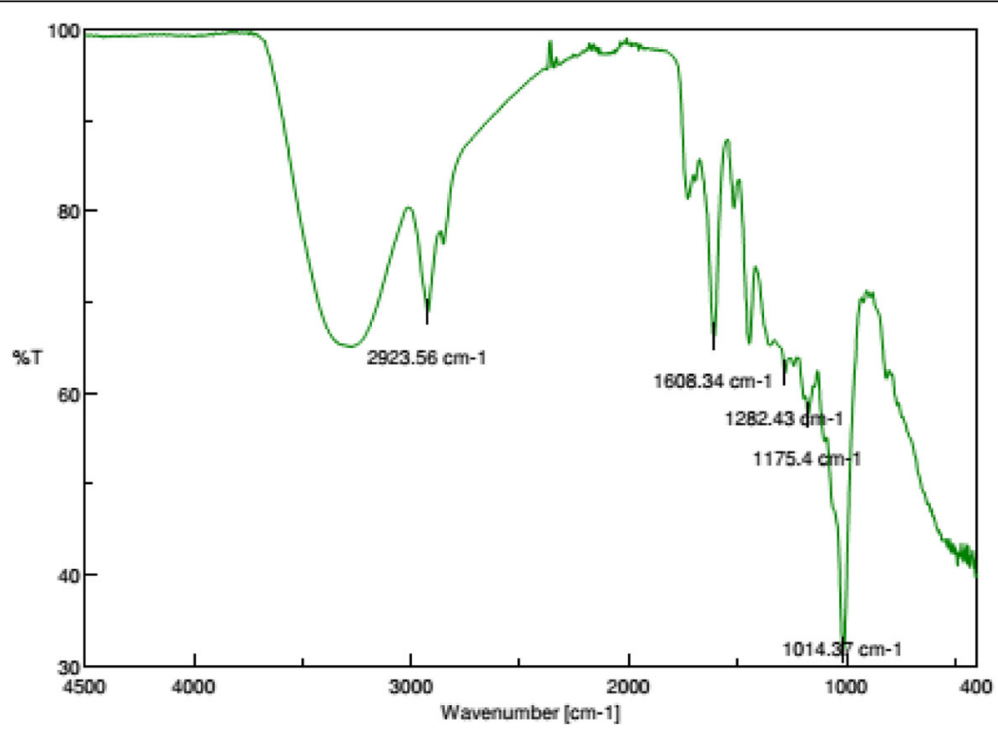

Fig. 1 Fourier transform infrared spectroscopy (FTIR) analyses ethanolic leaf extract of Combretum album 


\section{Abbreviations}

DMSO: Dimethyl Sulfoxide; FTIR: Fourier Transform Infrared

Spectrophotometer; MIC: Minimum inhibitory concentration; SD: Standard Deviation

\section{Acknowledgements}

The authors are grateful to Professor Dr. Ambarish Mukherjee, Department of Botany, The University of Burdwan for taxonomical authentication of the plant.

\section{Funding}

We are grateful to DST PURSE PHASE-II for providing fellowship to Sunanda Burman.

\section{Availability of data and materials}

All data generated or analysed during this study are included in this published article (However, raw data are available from the corresponding author on reasonable request).

\section{Authors' contributions}

SB collected the plant material, prepared the extracts, carried out the experiment and wrote the first draft of the manuscript. KB and DM analyzed the data, conducted statistical analysis and IR analysis and helped in manuscript preparation. GC designed the experiment, supervised the work, and helped in critical revision of the manuscript. All authors read and approved the final manuscript

\section{Ethics approval and consent to participate}

"Not applicable".

\section{Consent for publication}

"Not applicable".

\section{Competing interests}

"The authors declare that they have no competing interests."

\section{Publisher's Note}

Springer Nature remains neutral with regard to jurisdictional claims in published maps and institutional affiliations.

\section{Author details}

'Mosquito, Microbiology and Nanotechnology Research Units, Parasitology Laboratory, Department of Zoology, The University of Burdwan, Golapbag, Burdwan, West Bengal 713104, India. ${ }^{2}$ Department of Zoology, Durgapur Government College, JN Avenue, Durgapur 713214, India.

Received: 24 January 2018 Accepted: 26 June 2018

Published online: 11 July 2018

\section{References}

1. Coates A, Hu YM, Bax R, Page C. The future challenges facing the development of new antimicrobial drugs. Nat Rev Drug Discov. 2009;1: 895-910.

2. Levy SB. The antibiotic paradox: how the misuse of antibiotics destroys their curative powers. Cambridge. In: MA: Perseus publishing; 2002

3. Dahanukur SA, Kulkarni RA, Rege NN. Pharmacology of medicinal plants and natural products. Ind J Pharmacol. 2002:32:s81-s118.

4. Cowan MM. Plant products as antimicrobial agents. Clin Microbiol Rev. 1999;12:564-82.

5. Rawani A, Pal S, Chandra G. Evaluation of antibacterial properties of four plant extracts against human pathogens. Asian Pac J Trop Biomed. 2000;1: s71-5

6. Chatterjee SK, Bhattacharjee I, Chandra G. Bactericidal activities of some common herbs in India. Pharm Biol. 2007:45:350-4.

7. Abraham J, Chakraborty P, Chacko AM, Khare K. Cytotoxicity and antimicrobial effects of Pistia stratiotes leaves. Int J Drug Dev \& Res. 2014; 6(4):208-21

8. Bhattacharya K, Burman S, Nandi S, Roy P, Chatterjee D, Chandra G. Phytochemical extractions from the leaves of Ravenala madagasariensis from Sundarban area and its effect on southern house mosquito ( Culex quinquefasciatus Say 1823) larvae. J Mosq Res. 2014;4(12):1-6.
9. Singh A, Bhattacharya K, Chandra G. Efficacy of Nicotiana plumbaginifolia (Solanaceae) leaf extracts as larvicide against malarial vector Anopheles stephensi Liston 1901. Int J pharma bio Sci. 2015; 6(1): (b) 860-868.

10. Mukherjee D, Bhattacharya K, Chandra G. Extracts of edible pods of Moringa oleifera lam. (Moringaceae) as novel antibacterial agent against some pathogenic bacteria. Int J Pharma Bio Sci 2015; 6(3): (B) 513-520.

11. Dellavalle PD, Cabrera A, Alem D, Larrañaga P, Ferreira F, Rizza MD. Antifungal activity of medicinal plant extracts against phytopathogenic fungus Alternaria spp. Chil J Agri Res. 2011;71(2):231-9.

12. Baroni S, Suzuki-Kemmelmeier F, Caparroz-Assef SM, Cuman RKN, BersaniAmado CA. Effect of crude extracts of leaves of Smallanthus sonchifolius (Yacon) on glycemia in diabetic rats. Braz J Pharm Sci. 2008;44(3):511-30.

13. World Health Organization. International classification of diseases: $\left(9^{\text {th }}\right)$ ninth revision. In: Basic tabulation list with alphabetic index; 1978

14. Cragg GM, Newman DJ, Snader KM. Natural products in drug discovery and development. J Nat Prod. 1997;60:52-60.

15. Zwetlana A, Nandini M, Dorcas K. Antimicrobial activity of medicinal plant extracts on gram negative bacteria. J Med Plant Stud. 2014;2(5):51-4.

16. Abere TA, Agoreyo FO. Antimicrobial and toxicological evaluation of the leaves of Brassia axillaries Hua used in the management of HIV/AIDS patients. BMC Complement and Altern Med. 2006;6:22

17. Combretum roxburghii Spreng. The Plant List: A working list of all plant species. http://www.theplantlist.org/tpl1.1/record/kew-2732996. Accessed 19 July 2017.

18. Sanyal MN. Flora of Bankura District West Bengal, 1994. p.166.

19. Begum T, Amit Sarker A, Akhter S. Comparative study on Combretum and Terminalia species of the Combretaceae family. Pharmacophore. 2016;7(1): $41-3$

20. Chopra NR, Nayar S L, Chopra IC. Glossary of Indian medicinal plants (including the supplement). CSIR, New Delhi.1986.

21. Bhatnagar S, Sunita Sahoo S, Mohapatra AK, and Behera DR. Phytochemical analysis, antioxidant and cytotoxic activity of medicinal plant Combretum roxburghii (family: Combretaceae). January-march. 2012 2014; 4(1):193-202.

22. Singha Ray A, Bhattacharya K, Chandra G. Target specific larvicidal effect of Capparis zeylanica (Capparaceae) foliages against filarial vector Culex quinquefasciatus Say (1823). Int J pharm bio Sci. 2015; 6(3): (B) 139-148.

23. Bhattacharya K, Chandra G. Phagodeterrence, larvicidal and oviposition deterrence activity of Tragia involucrata L. (Euphorbiaceae) root extractives against vector of lymphatic filariasis Culex quinquefasciatus (Diptera: Culicidae). Asian Pac J Trop Dis. 2014:4(1):226-32.

24. Bhattacharjee I, Chatterjee SK, Ghosh A, Chandra G. Antibacterial activities of some plant extracts used in Indian traditional folk medicine. Asian Pac J Trop Biomed. 2011:s165-9.

25. National Committee for Clinical Laboratory Standards. Performance standards for antimicrobial disc susceptibility tests. Approved standard NCCLS Publications M2-A5. Villanova, PA, USA .1993.

26. Ncube NS, Afolayan AJ, Okoh Al. Assessment techniques of antimicrobial properties of natural compounds of plant origin: current methods and future trends. Afr J Biotechnol. 2008;7(12):1797-806.

27. Harborne JB. Phytochemical methods. 2nd ed. Chapman \& Hall: London 1984: 85: 196.

28. Sofowora A. Medicinal plants and medicine in Africa. Spectrum Books Ltd badan. 1993:150-3.

29. Mukhtar S, Ghori I. Antibacterial activity of aqueous and ethanolic extracts of garlic, cinnamon and turmeric against Escherichia coli ATCC 25922 and Bacillus subtilis DSM 3256. Int J Appl Biol Pharm. 2012;3(2):131-6.

30. Abkhoo J, Jahani S. Antibacterial effects of aqueous and ethanolic extracts of medicinal plants against pathogenic strains. Int J Inf Secur. 2017;4(2): e42624.

31. Bitchagno GTM, Fonkeng LS, Kopa TK, Tala MF, Wabo HK, Tume CB, Kuiate JR. Antibacterial activity of ethanolic extract and compounds from fruits of Tectona grandis (Verbenaceae). BMC Complement and Altern Med. 2015;15: 265.

32. Sharma S, Dangi MS, Wadhwa S, Daniel V, Tiwari A. Antibacterial activity of Cassia tora leaves. Int J Pharm \& Biol Arch. 2010;1(1):84-6.

33. Dubey S, Sinha DK, Murugan MS, Singh PL, Siddiqui MZ, Prasad N, Vadhana AP, Bhardwaj M, Singh BR. Antimicrobial activity of Ethanolic and aqueous extracts of common edible gums against pathogenic Bacteria of animal and human health significance. JPN. 2015;3(3):30-6.

34. Rabe T, Staden JV. Antibacterial activity of south African plants used for medicinal purposes. J Ethnopharmacol. 1997;56:81-7. 
35. Kumar M. Antibacterial activity of Combretum indicum (L.) DeFeilipps flower extracts against gram positive and gram-negative human pathogenic bacteria. World. J Pharm Pharm Sci. 2015;4(10):1288-97.

36. Oghenejobo M, Oghenejobo BUS, Uvieghara KE, Omughele E.

Phytochemical screening and antimicrobial activities of the fractionated leaf extracts of Combretum racemosum. Sch Acad J Pharm. 2014;3(6):455-62.

37. Panda SK, Mohanta YK, Padhi L, Park YH, Mohanta TK, Bae H. Large scale screening of ethnomedicinal plants for identification of potential antibacterial compounds. Molecules. 2016;21 (293):1-20

38. Hideyuki I, Koji Y, Tae-Hoon K, Khennouf S, Gharzouli K, Yoshida T. Dimeric and trimeric hydrolysable tannins from Quercus coccifera and Quercus suber. J Nat Prod. 2002;65:339-45.

39. Meng Z, Zhou Y, Lu J, Sugahara K, Xu S, Kodama H. Effects of five flavonoid compounds isolated from Quercus dentata on superoxide generation in human neutrophils and phosphorelatioion of neutrophil proteins. Clin Chim Acta. 2001;306:97-102.

40. Agarwal VS. Drugs plants of India. Ludhiana: Kalyani Publishers. 1997;1:182-3.

41. Zahner H., Fiedler HP. The need for new antibiotics: possible ways forward. In P. A. Hunter PA., Darby J., Russell NJ. Fifty years of antimicrobials: past perspectives and future trends. Proceedings of Fifty-Third Symposium of the Society for General Microbiology Cambridge University Press, Cambridge, United Kingdom. 1995

Ready to submit your research? Choose BMC and benefit from:

- fast, convenient online submission

- thorough peer review by experienced researchers in your field

- rapid publication on acceptance

- support for research data, including large and complex data types

- gold Open Access which fosters wider collaboration and increased citations

- maximum visibility for your research: over $100 \mathrm{M}$ website views per year

At BMC, research is always in progress.

Learn more biomedcentral.com/submissions 